\title{
Operation and Design of Scrap Melting Process of the Packed Bed Type
}

\author{
Takaiku YAMAMOTO, Yutaka UJISAWA, Hiroaki ISHIDA and Kouji TAKATANI
}

Corporate Research \& Development Laboratories, Sumitomo Metal Industries, Ltd., 16-1, Sunayama, Hasaki-machi, Kashima-gun, Ibaraki-ken, 314-02 Japan.

(Received on February 16, 1999; accepted in final form on April 14, 1999)

A coke Packed bed type Scrap Melting process (PSM) with simultaneous high-rate injection of oxygen and pulverized coal was proposed which aims to achieve high heat efficiency, high productivity, high Fe yield and low refractory erosion with using not only shaft type furnaces but also basic oxygen converter (BOF) vessel.

The experiments were made to verify the usefulness of the proposed process using the modified experimental blast furnace of 1 ton pig per tap scale and the modified experimental BOF of 10 ton pig per tap scale. A 3-dimensional mathematical simulation model was also developed in order to elucidate the physical and chemical conditions inside the furnace on the basis of transport phenomena and to make a basic design of commercial scale plant. Obtained results were summarized as follows:

1) $100 \%$ steel scrap can be melted into well carburized and well desulpherized pig iron using both 1 ton scale blast furnace and 10 ton scale BOF.

2) The heat efficiency of about $80 \%$, the productivity per unit furnace volume of about $50 \mathrm{t} / \mathrm{d} \cdot \mathrm{m}^{3}, \mathrm{Fe}$ yield of more than $99 \%$ and the erosion rate of refractory of less than $0.5 \mathrm{~mm} / \mathrm{charge}$ were achieved throughout the experiments.

3) These results were well justified by the 3-dimensional mathematical simulation model.

4) A basic design of commercial scale plant was also performed by the use of the model.

KEY WORDS: scrap melting; coke packed bed; pulverized coal; oxygen; post combustion; experimental blast furnace; experimental basic oxygen converter; mathematical model; scale up; commercial scale plant.

\section{Introduction}

Recycling of iron scrap is expected as a countermeasure for the effective utilization of resources and against the global warning by carbon dioxide $\left(\mathrm{CO}_{2}\right){ }^{1)}$ In recent years the amount of old scrap is increasing steadily by about one million tons per year in Japan. This tendency would continue in the future. ${ }^{2)}$ Therefore the integrated steel plant should develop the scrap melting process immediately with use of its advantages. Two methods which use the blast furnace ${ }^{31}$ and basic oxygen converter $(B O F)^{4)}$ are considered as the method to utilize the equipments in the plant. Although the equipment of BOF is simpler than that of blast furnace, there is some room to improve the heat efficiency and refractory life. Therefore, we should choose the best method after the various investigations has been performed in the future. From these points, the new scrap melting process (PSM: Packed bed type Scrap Melting process) ${ }^{5)}$ which can applied the equipment of BOF was developed by Sumitomo Metal Industries, Ltd.

As the melting furnace is a kind of vertical furnace which has coke packed bed ${ }^{6)}$ and its heat exchange between gas and solid is countercurrent flow, it is con- sidered to be superior to in-bath smelting with use of BOF in regard to heat efficiency and refractory life.

In this paper, we describe a summary of the scrap melting tests made to verify the usefulness of the proposed process using a modified experimental blast furnace of 1 ton pig per tap scale and a modified experimental BOF of 10 ton pig per tap scale first. Next, we discuss a 3-dimensional mathematical simulation model which was also developed in order to understand the internal scrap melting behavior inside the furnace and establish the technology of scaling up the process.

\section{Concept of PSM Process}

Figure 1 shows the concept of PSM process schematically. The melting furnace has a charging systems of scrap and coke and discharging exhaust gas at the top of the furnace with plural primary tuyeres in its lower portion and plural secondary tuyeres in the side wall at a level above the primary tuyeres. The furnace is equipped with a tapping hole for hot metal and slag at a level between the primary tuyeres and bottom tuyeres. The air or highly oxygen-containing gas is blown into the furnace of high temperature coke packed 


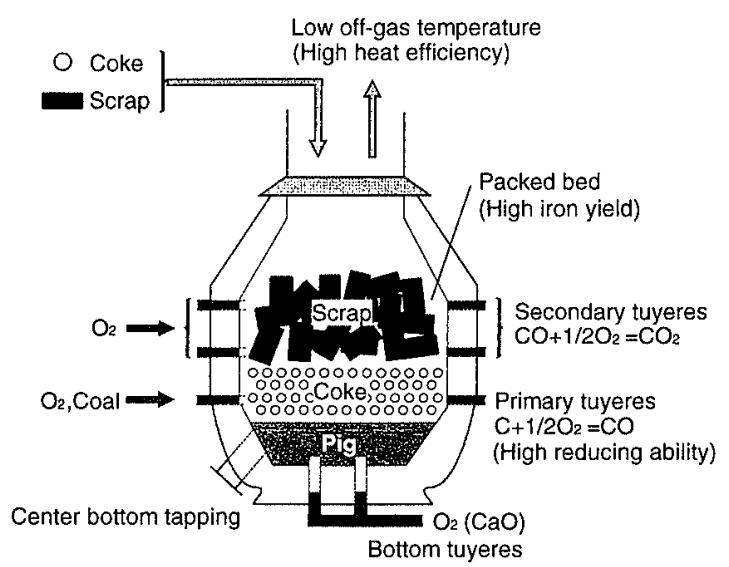

Fig. 1. Concept of the PSM process.

bed from the primary tuyeres if necessary with pulverized coal injection and then coke and pulverized coal are burnt in front of the tuyeres according to Eq. (1).

$$
\mathrm{C}+1 / 2 \mathrm{O}_{2}=\mathrm{CO}+29.4 \mathrm{Mcal} / \mathrm{kmol}-\mathrm{C}
$$

The scrap is melted by the sensible heat of the high temperature reducing gas produced by the combustion. On the other hand, the scrap is preheated by the gas streaming upward after melting the scrap. The post combustion expressed by Eq. (2) is caused by the air or oxygen- containing gas injection into the shaft from the secondary tuyeres promotes the scrap heating.

$$
\mathrm{CO}+1 / 2 \mathrm{O}_{2}=\mathrm{CO}_{2}+67.6 \mathrm{Mcal} / \mathrm{kmol}-\mathrm{CO}
$$

Features of the PSM process are summarized as follows.

1) As countercurrent heat transfer occurs in the furnace with the packed bed of scrap and coke, the total heat efficiency(over $80 \%$ : see Fig. 12) remains higher than that (about $70-75 \%{ }^{71}$ ) of EAF (Electric Arc Furnace) or that (about $60 \%{ }^{8)}$ ) of in-bath smelting method.

2) The iron yield is higher than that of in-bath smelting method by the packed bed method.

3) As the refractory is protected from high temperature atmosphere in the furnace by the packed scrap and coke, its refractory erosion is lower than that of in-bath smelting method.

4) Blast furnace coke with a large quantity of pulverized coal instead of high quality as foundry coke which is necessary for conventional cupola is available for PSM.

5) Although the high-grade coke with low reactivity and large size is burnt nearly to $\mathrm{CO}_{2}\left(\mathrm{C}+\mathrm{O}_{2}=\mathrm{CO}_{2}\right)$ in conventional cupola, the ordinary coke for blast furnace is burnt to $\mathrm{CO}$ according to Eq. (1) in PSM. Therefore, although reducing ability in the lower part of the furnace in conventional cupola is low, it is so high in PSM that the hot metal whose quality is equal to that of blast furnace is produced with high carburization and high desulfurization using 100\% steel scrap.

6) The fuel efficiency and productivity is increased by the post combustion according to Eq. (2) with the air or oxygen-containing gas injection from the secondary tuyeres much more than these of blast furnace method. ${ }^{9)}$

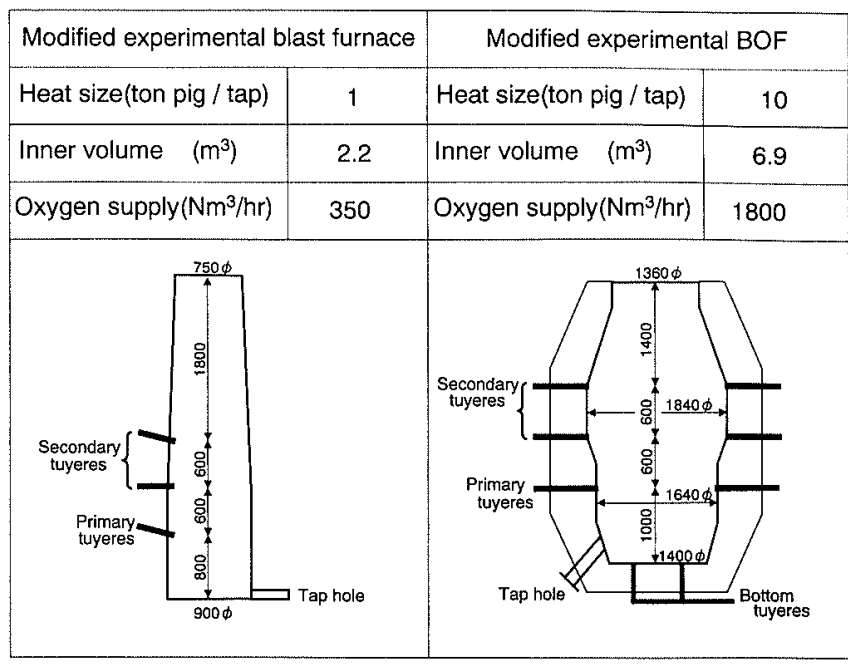

Fig. 2. Configuration of the experimental furnaces.

Table 1. Chemical analysis of raw materials.

\begin{tabular}{|l|c|c|c|c|c|c|}
\hline & $\mathrm{C}$ & $\mathrm{H}$ & $\mathrm{O}$ & $\mathrm{N}$ & $\mathrm{S}$ & Ash \\
\hline Coke & 87 & 0.2 & - & 1.1 & 0.6 & 11.1 \\
\hline Coal & 75 & 4.5 & 7.7 & 1.4 & 0.6 & 11.0 \\
\hline
\end{tabular}

7) Although a shaft type furnace such as conventional cupola is suitable for the furnace body, a conventional BOF converter is also available for its body.

\section{Experimental Method}

\subsection{Experimental Apparatus}

After the fundamental functions of PSM process was proved using a modified experimental blast furnace of 1 ton pig per tap scale, the scaling up test was performed using a modified experimental BOF of 10 ton pig per tap scale. Figure $\mathbf{2}$ schematically illustrates the configuration of experimental furnaces. The 1 ton furnace has three primary tuyeres installed at 120 degree circumferential intervals and three lower and upper secondary tuyeres were installed above the primary tuyeres, respectively. On the other hand, the 10 ton BOF has four primary tuyeres installed at 90 degree circumferential intervals and six lower and upper secondary tuyeres were installed above the primary tuyeres, respectively. Furthermore, two bottom tuyeres were equipped in order to control the temperature and $\mathrm{Si}$ content of hot metal.

\subsection{Material Condition}

Table 1 shows the properties of raw material used in the present experiments. Sized coke for blast furnace and non-coking coal with volatile matter of $35 \%$ after pulverized into the size of $80 \%$ under 200 mesh were used as fuels. Limestone or calcium oxide and serpentine were used to adjust the basicity and $\mathrm{MgO}$ content of slag, respectively. Steel scrap whose purity of iron has 99 mass\% Fe was used in the tests.

\subsection{Operational Condition}

Table 2 shows the standard operational conditions for the 1 ton furnace and the 10 ton BOF. 
Table 2. Experimental conditions.

\begin{tabular}{|c|c|c|c|c|c|}
\hline & 1 ton furnace & 10 ton furnace \\
\hline \multicolumn{2}{|l|}{ Operation time } & \multicolumn{2}{|c|}{ hour/campaign } & 120 & 24 \\
\hline \multicolumn{2}{|l|}{ Tapping } & \multicolumn{2}{|c|}{ ton/tap } & $T$ & 10 \\
\hline \multicolumn{2}{|c|}{ Average tap to tap } & \multicolumn{2}{|c|}{ hour/tap-tap } & 1 & 1 \\
\hline \multirow[t]{2}{*}{ Scarp } & \multicolumn{2}{|c|}{ Weight } & $\mathrm{kg} / \mathrm{piece}$ & $\max 15$ & $\max 100$ \\
\hline & \multicolumn{2}{|c|}{ Bulk density } & $\mathrm{kg} / \mathrm{m}^{3}$ & $3.5 \times 10^{3}$ & $3.0 \times 10^{3}$ \\
\hline \multirow[t]{2}{*}{ Coke } & \multicolumn{2}{|l|}{ Size } & $\mathrm{mm}$ & $25 \sim 50$ & $50 \sim 80$ \\
\hline & \multicolumn{3}{|c|}{ Bulk density } & 540 & 500 \\
\hline $\begin{array}{l}\text { Total oxygen } \\
\text { blowing }\end{array}$ & \multicolumn{3}{|c|}{$\mathrm{Nm}^{3} / \mathrm{h}$} & $\max 350$ & $\max 1800$ \\
\hline Coke/Fuel & Ratic & & - & $1 \sim 0.25$ & $1 \sim 0.25$ \\
\hline $\begin{array}{l}\text { Production } \\
\text { rate }\end{array}$ & \multicolumn{3}{|c|}{$\mathrm{tHM} / \mathrm{h}$} & $\begin{array}{c}\text { approx. } \\
2\end{array}$ & $\begin{array}{r}\text { approx. } \\
15\end{array}$ \\
\hline
\end{tabular}

Table 3. Chemical analysis of hot metal and slag.

\begin{tabular}{|c|c|c|c|}
\hline \multirow{6}{*}{ Hot metal } & [C] & \multirow{5}{*}{$w t-\%$} & 4.5 \\
\hline & [Si] & & 0.1 \\
\hline & [Mn ] & & 0.4 \\
\hline & {$[\mathrm{P}]$} & & 0.025 \\
\hline & S] & & 0.025 \\
\hline & Temperature & ${ }^{\circ} \mathrm{C}$ & $1400 \sim 1500$ \\
\hline \multirow[t]{2}{*}{ Slag } & $\left(\mathrm{CaO} / \mathrm{SiO}_{2}\right)$ & - & $1.0 \sim 1.2$ \\
\hline & Volume & $\mathrm{kg} / \mathrm{tHM}$ & $20 \sim 30$ \\
\hline
\end{tabular}

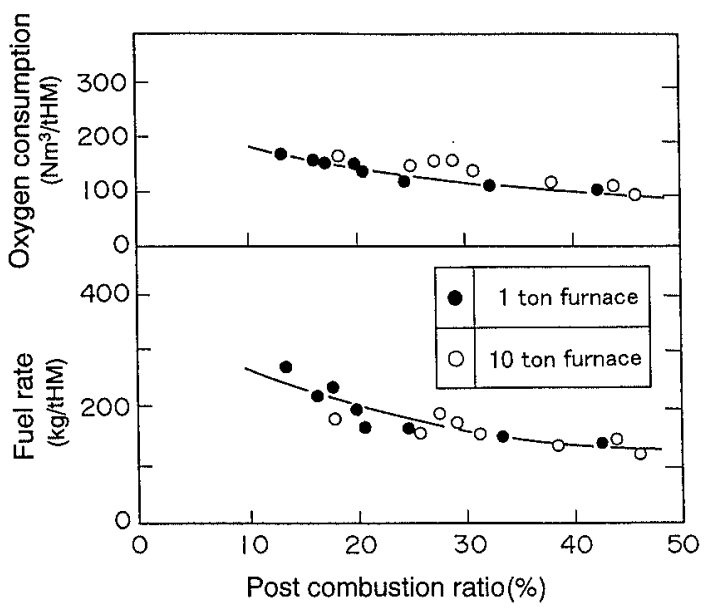

Fig. 3. Influence of post combustion on fuel rate and oxygen consumption.

\section{Experimental Results}

The tests on both of the furnaces were performed entirely smoothly. As a results it was confirmed that it is sufficiently possible to apply PSM process to BOF type furnace. As the lower part of the furnace was maintained at high temperature and reducing atmosphere by the coke packed bed, the hot metal whose quality is equal to that of blast furnace was produced with high carburization, high desulfurization and trace $\mathrm{Si}$ content. The average compositions of pig iron are shown in Table 3 . The fuel and oxygen consumption in the tests were summarized in Fig. 3. It was verified that the fuel and oxygen consumption was decreased by the increase of post combustion. Figure 4 shows the relationship between post combustion and heat efficiency in the 10 ton furnace. The heat efficiency of more than $80 \%$ was achievable when the post combustion ratio reached nearly $30 \%$ and the off gas temperature was less than $500^{\circ} \mathrm{C}$ because the heat generated by the post combustion was operated effectively to heat the scrap. Figure 5 shows an example of heat balance in the 10 ton furnace when the post combustion ratio was equal to $30 \%$. At that time, scrap of 7.5 ton per charge was melted completely within

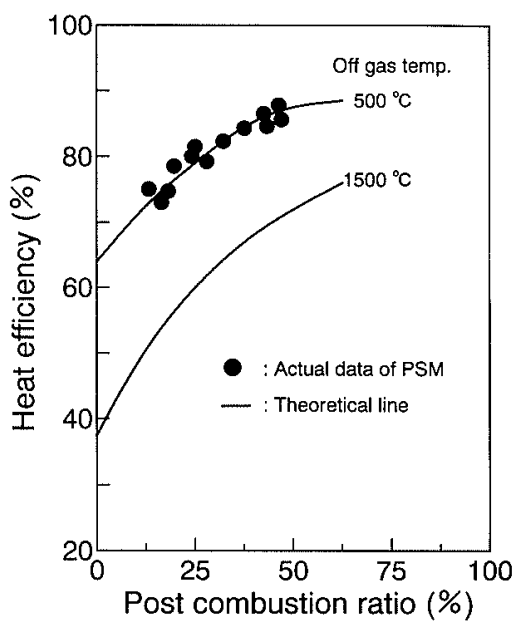

Fig. 4. Influence of post combustion on heat efficiency.

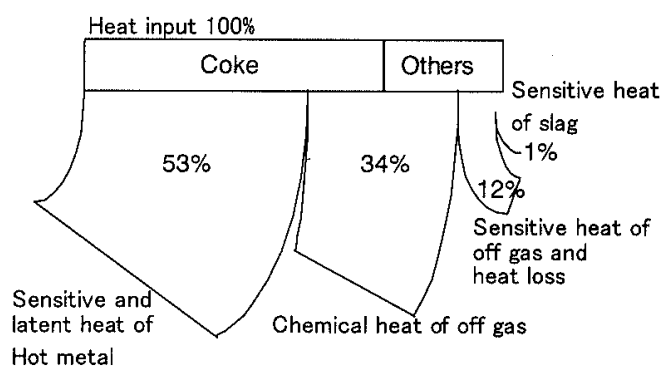

Fig. 5. Example of heat balance.

around 30 minutes and the production rate of molten iron was equivalent to around $50 \mathrm{t} / \mathrm{d} \cdot \mathrm{m}^{3}$. The iron yield of more than $99 \%$ was obtained and the average refractory erosion was maintained at low erosion level of less than $0.5 \mathrm{~mm}$ per charge through the all test period in both of the furnaces.

$$
\text { Post combustion }(\%)=\frac{\mathrm{CO}_{2}+\mathrm{H}_{2} \mathrm{O}}{\mathrm{CO}+\mathrm{CO}_{2}+\mathrm{H}_{2} \mathrm{O}} \times 100
$$

Hest efficiency $(\%)=$

$$
\frac{\text { Heat of hot metal }}{\text { Heat input }- \text { Chemical heat of off gas }} \times 100
$$

\section{Development of a 3-Dimensional Mathematical Simulation Model}

PSM process is a packed bed type reactor such as blast furnace or cupola which is a continuous countercurrent process between gas and solid or liquid with simultaneous heat and mass transfer as well as many chemical reactions. Therefore, a lot of attempts, laboratory scale experiments and dissection investigations of the reactors have been studied for the better understanding of these complicated phenomena concerning physical and chemical mechanisms. On the other hand, by the use of these works, all kinds of mathematical models have also been constructed in order to estimate quantitatively the phenomena occurring in the reactor. In recent years complex analysis has become possible because of the improvement of the ability of the digital computer and numerical analysis technology. A 3-dimensional mathe- 
matical simulation model ${ }^{10.11)}$ that can describe three dimensional and unsteady state of the internal behavior that could not treated by the previous models ${ }^{12-16)}$ was developed in order to design the process and improve its operation systematically based on understanding dynamical and physical transport phenomena with chemical reactions inside the reactor.

\subsection{Modeling}

The governing equations to describe the internal behavior was composed of three dimensional and dynamic equations in order to design the reactor profile, that is, to study the effects of arrangement of tuyeres and deflection of gas and solid flow in the circumferential and radial direction and radial direction on the operational results and to design the unsteady state operational method in the same way as the actual operation. The following assumptions and simplification were made in the model.

1) Three phases (gas, solid and liquid) exist inside the furnace.

2) Species of gas are considered $\mathrm{CO}, \mathrm{CO}_{2}, \mathrm{H}_{2}, \mathrm{H}_{2} \mathrm{O}$, $\mathrm{N}_{2}$ and $\mathrm{O}_{2}$.

3) Species of scrap and coke are Fe, etc and C, etc. respectively.

4) Species of liquid are $\mathrm{Fe}, \mathrm{C}$ and etc.

5) Considering main chemical reactions occurring in the reactor with reaction rate equations.

6) Ergun equation ${ }^{17)}$ is applied to gas flow in the packed bed.

7) Kinematic model ${ }^{18)}$ is applied to solid flow of burden materials.

8) Liquid is assumed to move to the gravity direction with a constant dripping velocity.

9) Density of gas is calculated according to ideal gas equation.

10) Temperature of scrap and coke of solid phase is assumed to be same and that of metal and slag in liquid phase is assumed to be same.

11) Heat balance is considered for each phase by taking account of the heat reactions, heat exchange, heat conduction and heat loss. However, heat conduction is not considered for liquid phase in dispersive phase.

\subsection{Governing Equations}

The governing equations are written for mass, momentum and energy in the following form.

\subsubsection{Mass Balance}

$$
\frac{D\left(\varepsilon_{j} \rho_{j} \xi_{j i}\right)}{D t}=\varepsilon_{j} \operatorname{div}\left(\rho_{j} D_{j} \operatorname{grad} \xi_{j i}\right)+M_{i} \sum_{n} \operatorname{Rate}_{n} a_{j i n}
$$

Mass balance equation is written as follows by summation of mass fraction at each phase :

$$
\frac{D\left(\varepsilon_{j} \rho_{j}\right)}{D t}=\sum_{i=1}^{N}\left(M_{i} \sum_{n} \text { Rate }_{n}\right) a_{j i n}
$$

Where, it is necessary to consider mixing and diffusion phenomena among gases in order to evaluate the effect of post combustion reaction inside the packed bed on the reactor efficiency appropriately when a relatively low height reactor such as BOF type furnace is used for the

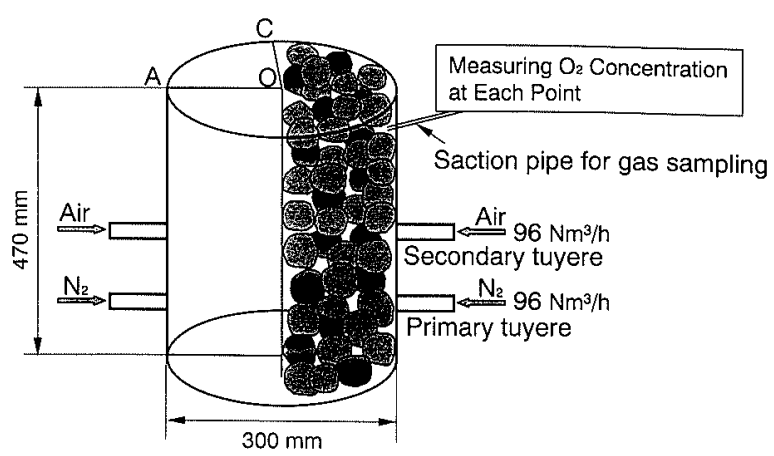

Fig. 6. Experimental apparatus for the investigation of the mechanism of gas diffusion through the packed bed.

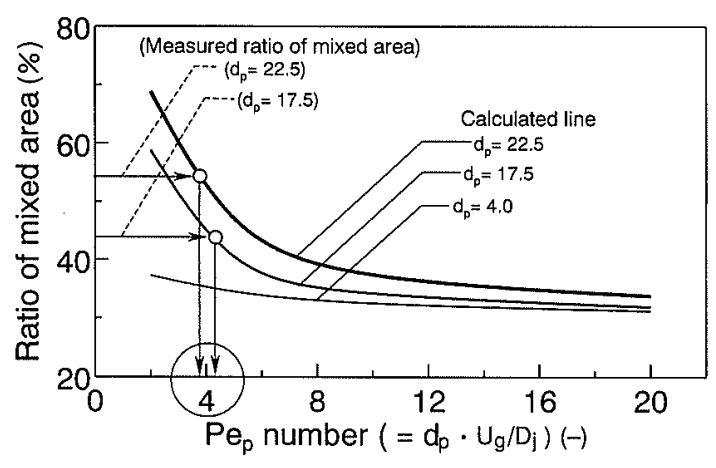

Fig. 7. Effect of particle diameter on the gas diffusion.

PSM process. The diffusion of gas phase is considered in the first term of right hand side of Eq. (5). The only dimensionless number to govern the gas diffusion is Peclet number $\left(\mathrm{Pe}_{\mathrm{p}}\right)$ that means the ratio of bulk mass transport and mass transfer by the diffusion as shown in Eq. (7).

$$
\mathrm{Pe}_{\mathrm{p}}=\frac{d_{\mathrm{p}} \cdot U_{\mathrm{g}}}{D_{j}}
$$

$\mathrm{Pe}_{\mathrm{p}}$ in packed bed is known to be a constant value. ${ }^{19)}$ However, the $\mathrm{Pe}_{\mathrm{p}}$ in three dimensional state has not yet been investigated. Therefore, a cold model test was carried out in order to investigate the mechanism of gas diffusion through the packed bed. The experimental apparatus is shown in Fig. 6. After packing particles, nitrogen and air were injected from the primary and secondary tuyeres, respectively and the oxygen concentration was measured at each point in order to evaluate the mixing and diffusion phenomena among gases quantitatively. The degree of the mixing and diffusion among gases (called mixed area) was evaluated by the area of oxygen concentration range from 5 to 15 volume percent. The $\mathrm{Pe}_{\mathrm{p}}$ was determined to compare the experimental mixed area with the calculated one on the basis of the relationship between mixed area and $P e_{p}$ simulated by the model as shown in Fig. 7. It is apparent from Fig. 8 that the calculated values by the determined $\mathrm{Pe}_{\mathrm{p}}(=4)$ agreed well with the experimental ones. ${ }^{20)}$

\subsubsection{Momentum Balance}

(1) Gas Phase

$$
\frac{\partial\left(\varepsilon_{\mathrm{g}} \rho_{\mathrm{g}} U_{\mathrm{g}}\right)}{\partial t}=-\varepsilon_{\mathrm{g}} \operatorname{grad} P-\varepsilon_{\mathrm{g}}\left(f_{1}+f_{2}\left|\varepsilon_{\mathrm{g}} \rho_{\mathrm{g}} U_{\mathrm{g}}\right|\right)\left(\varepsilon_{\mathrm{g}} \rho_{\mathrm{g}} U_{\mathrm{g}}\right)
$$




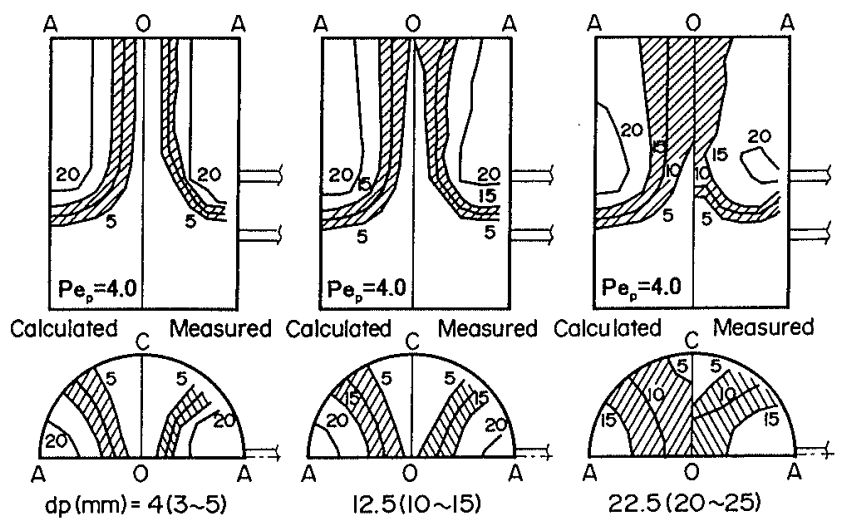

Fig. 8. Determination of Peclet number in the packed bed.

$$
f_{1}=150\left(\frac{1-\varepsilon_{\mathrm{g}}}{\varepsilon_{\mathrm{g}} \phi d_{\mathrm{p}}}\right)^{2} \frac{\mu_{\mathrm{g}}}{\rho_{\mathrm{g}}}, \quad f_{2}=1.75\left(\frac{1-\varepsilon_{\mathrm{g}}}{\varepsilon_{\mathrm{g}} \phi d_{\mathrm{p}}}\right) \frac{1}{\varepsilon_{\mathrm{g}}^{2} \rho_{\mathrm{g}}}
$$

(2) Solid Phase

The kinematic model which has been confirmed to be useful through a 3-dimensional cold model experiment for burden descent ${ }^{21)}$ was applied as the equation of motion for the solid. The governing equation of kinematic model is given by the following equation when the coordinate of $X_{\mathrm{j}}$ is in the gravity direction:

$$
U_{\mathrm{s} i}=B \frac{\partial U_{\mathrm{s} j}}{\partial X_{i}}, \quad U_{\mathrm{s} k}=B \frac{\partial U_{\mathrm{s} j}}{\partial X_{k}}
$$

(3) Liquid Phase

Motion of liquid was assumed to drip vertically as a plug flow as follows:

$$
U_{1 j}=\text { const. }, \quad U_{1 i}=U_{1 k}=0
$$

5.2.3. Energy Balance

$$
\begin{aligned}
\frac{D\left(\varepsilon_{j} \rho_{j} C_{\mathrm{p} j} T_{j}\right)}{D t}= & \varepsilon_{j} \operatorname{div}\left(k_{j} \operatorname{grad} T_{j}\right) \\
& +\sum_{m}\left\{a_{j m} u_{j m}\left(T_{m}-T_{j}\right)\right\}+R H_{j}
\end{aligned}
$$

Where,

$$
\frac{D()}{D t}=\frac{\partial()}{\partial t}+U_{i} \frac{\partial()}{\partial X}, \quad R H_{j}=\sum_{n} \operatorname{Rate}_{n}\left(-\Delta H_{n}\right) \eta_{j n}
$$

\subsection{Chemical Reactions}

Main reactions occurring in the furnace were considered as reaction rate equations in the model. The reactions are shown in Table 4 . It is possible to evaluate the effect of the post combustion in the packed bed that is one of the most important factors to govern PSM process with gas-gas reactions No. 2, 3 by oxygen injected from the secondary tuyeres and solid -gas reaction No. 1 as shown in Table 4 . Temperature recovery method ${ }^{22}$ ) was applied to the melting of scrap (reaction No. 7).

\subsection{Process Parameters}

Process parameters that are necessary for the simulation were applied to the reference values shown in

\begin{tabular}{|c|c|c|c|}
\hline$n$ & \multicolumn{2}{|l|}{ Chemical reactions $\left(\right.$ Rate $\left._{\mathrm{n}}\right)$} & Ref. \\
\hline 1 & \multicolumn{2}{|l|}{$\mathrm{C}(\mathrm{s})+1 / 2 \mathrm{O}_{2}(\mathrm{~g}) \rightarrow \mathrm{CO}(\mathrm{g})$} & 23 \\
\hline 2 & \multicolumn{2}{|c|}{$\mathrm{CO}(\mathrm{g})+1 / 2 \mathrm{O}_{2}(\mathrm{~g}) \rightarrow \mathrm{CO}_{2}(\mathrm{~g})$} & Mixing control \\
\hline 3 & \multicolumn{2}{|l|}{$\mathrm{H} 2(\mathrm{~g})+1 / 2 \mathrm{O}_{2}(\mathrm{~g}) \rightarrow \mathrm{H}_{2} \mathrm{O}(\mathrm{g})$} & Mixing control \\
\hline 4 & \multicolumn{2}{|l|}{$\mathrm{C}(\mathrm{s})+\mathrm{CO}_{2}(\mathrm{~g}) \rightarrow 2 \mathrm{CO}(\mathrm{g})$} & 24 \\
\hline 5 & \multicolumn{2}{|c|}{$\mathrm{C}(\mathrm{s})+\mathrm{H}_{2} \mathrm{O}(\mathrm{g}) \rightarrow \mathrm{CO}(\mathrm{g})+\mathrm{H}_{2}(\mathrm{~g})$} & 24 \\
\hline 6 & \multicolumn{2}{|c|}{$\mathrm{H}_{2} \mathrm{O}(\mathrm{g})+\mathrm{CO}(\mathrm{g})=\mathrm{H}_{2}(\mathrm{~g})+\mathrm{CO}_{2}(\mathrm{~g})$} & Equilibrium \\
\hline 7 & \multicolumn{2}{|c|}{$\mathrm{Fe}(\mathrm{s}) \rightarrow \mathrm{Fe}(\mathrm{l})$ (Melting rate) } & 22 \\
\hline 8 & \multicolumn{2}{|l|}{$3 \mathrm{Fe}(1)+\mathrm{C}(\mathrm{s}) \rightarrow \mathrm{Fe}_{3} \mathrm{C}(\mathrm{l})$} & Equilibrium \\
\hline \multicolumn{2}{|r|}{ Process parameters } & Symbol & Ref. \\
\hline \multicolumn{2}{|c|}{$\begin{array}{l}\text { Effective thermal conductivity } \\
\text { for solid phase }\end{array}$} & $k_{5}$ & 27 \\
\hline \multicolumn{2}{|c|}{$\begin{array}{l}\text { Thermal diffusion coefficient } \\
\text { for gas phase }\end{array}$} & $\mathrm{k}_{\mathrm{g}}$ & 28 \\
\hline \multicolumn{2}{|c|}{ Gas-solid heat transfer coefficient } & $\mathrm{U}_{\mathrm{gs}}$ & 25 \\
\hline \multicolumn{2}{|c|}{ Gas-liquid heat transfer coefficient } & $\mathrm{u}_{\mathrm{g}^{\prime}}$ & $=0$ \\
\hline \multicolumn{2}{|c|}{ Liquid-solid heat transfer coefficient } & $\mathrm{u}_{18}$ & 26 \\
\hline \multicolumn{2}{|c|}{ Gas-solid effective contact area } & $\mathrm{a}_{93}$ & $=a_{a \| l} a_{1 s}$ \\
\hline \multicolumn{2}{|c|}{ Gas-liquid effective contact area } & $a_{8 !}$ & 29 \\
\hline \multicolumn{2}{|c|}{ Liquid-sold effective contact area } & $a_{15}$ & 30 \\
\hline
\end{tabular}
Table 4. It should be noted that liquid-solid heat transfer coefficient at the dripping zone had to be reduced to half of the original value ${ }^{25)}$ quoted in the model based on
Table 4. Chemical reactions and process parameters in the model.

Where, $a_{\text {all }}$ : Total contact area of solid phase

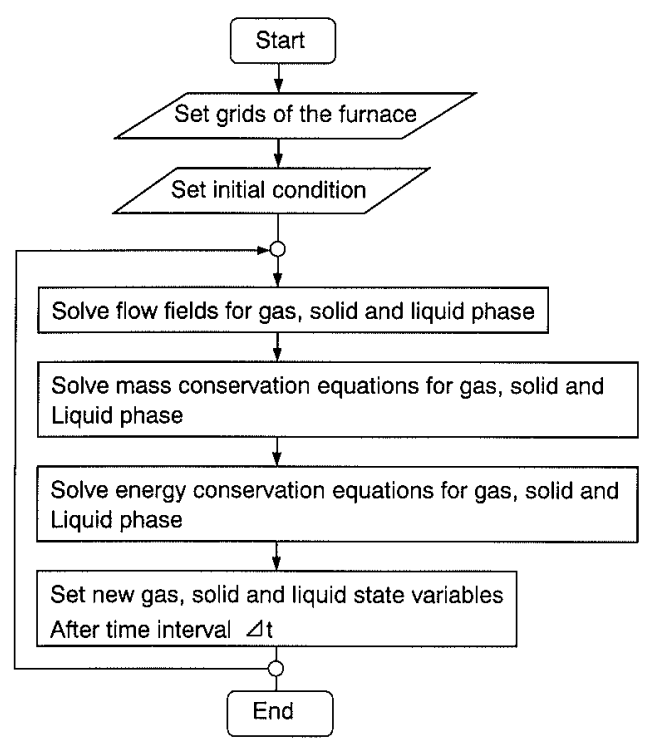

Fig. 9. Flow chart of the solution procedure.

analysis of operational results.

\subsection{Boundary Condition}

1) Scrap and coke were assumed to be continuously charged into the furnace from the top with mixed charging or separated charging and the liquid was assumed to be continuously discharged from the bottom of the furnace.

2) Blowing conditions are set at the primary and secondary tuyeres in the same way as the actual operation.

3) Heat transfer into the refractory is described by one dimensional heat conduction model in the thickness direction.

\subsection{Solution Procedure}

The differential equations to be solved numerically are above mentioned Eqs. (1)-(6) and these equations are dynamically calculated by the time difference $\Delta t$ on the basis of the appropriate boundary condition and the initial condition. The flow chart of the solution procedure in this model is shown in Fig. 9. As computation cells, 
staggered grids were used and a finite difference method based on Gauss's divergence theorem ${ }^{31)}$ was applied to represent the reactor shape exactly. The analysis algorithm of gas flow was applied SOLA algorithm ${ }^{32)}$ that is frequently used for numerical fluid dynamics. Mass and energy conservation equations for each phase were discretized by the implicit scheme and solved by the point

Table 5. Operational conditions of 1 ton furnace.

\begin{tabular}{|c|c|c|}
\hline Items & Unit & Conditions \\
\hline Burden & \multirow{5}{*}{$\begin{array}{l}\mathrm{mm} \\
\mathrm{mm} \\
- \\
\mathrm{m}\end{array}$} & \multirow{5}{*}{$\begin{array}{l}150 \square \times 20 t \\
20 \sim 50 \\
\text { mixed } \\
16\end{array}$} \\
\hline Scarp size & & \\
\hline Coke size & & \\
\hline Charging pattern & & \\
\hline Stock level & & \\
\hline Blowing & \multirow{9}{*}{$\begin{array}{l}\text { pieces } \\
\mathrm{Nm}^{3} / \mathrm{hr} \\
\mathrm{Nm}^{3} / \mathrm{hr} \\
- \\
\mathrm{Nm}^{3} / \mathrm{hr} \\
{ }^{\circ} \mathrm{C} \\
\text { pieces } \\
\mathrm{Nm}^{3} / \mathrm{hr}\end{array}$} & \multirow{9}{*}{$\begin{array}{l}3 p \\
207 \\
61 \\
1.0 \\
622 \\
2847 \\
3 p \\
207\end{array}$} \\
\hline Primary tuyeres & & \\
\hline $\mathrm{O}_{2}$ supply & & \\
\hline $\mathrm{N}_{2}$ supply & & \\
\hline $\mathrm{Coal} / \mathrm{O}_{2}$ & & \\
\hline Bosh gas volume & & \\
\hline Flame temperature & & \\
\hline Secondary tuyeres & & \\
\hline Air supply & & \\
\hline Productivity & \multirow{3}{*}{$\begin{array}{l}\mathrm{tHM} / \mathrm{day} / \mathrm{m}^{3} \\
\mathrm{Nm}^{3} / \mathrm{hr} / \mathrm{m}^{3}\end{array}$} & \multirow{3}{*}{$\begin{array}{l}18 \\
114\end{array}$} \\
\hline Production rate & & \\
\hline $\mathrm{O}_{2}$ supply & & \\
\hline
\end{tabular}

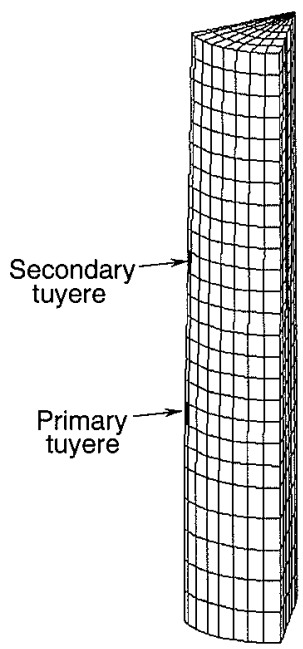

Fig. 10. Grids of 1 ton furnace.
SOR method. ${ }^{33)}$

\section{Computed Results}

The validity of the model was evaluated by comparison between the operational results of the above mentioned test furnaces and the computed results and the internal behavior of the process was discussed. As a results, the estimation of the internal behavior of PSM and the operational design of commercial scale PSM process became possible by the model.

\subsection{Results on the 1 Ton Test Furnace}

In order to study the verification of the present model as a total simulator, the computer simulation was performed for a practical operation of the 1 ton test furnace and the calculated results were compared with the actual test results. The operational condition for the calculation is shown in Table 5. The computational grids are shown in Fig. 10. The internal behavior of the furnace calculated by the model is shown in Fig. 11. The calculated gas flow pattern in the furnace shows almost plug flow in the region above the primary tuyere level except for the zone in front of the tuyeres. The calculated solid flow was also found to be plug flow in the region above the primary tuyere level. The solid velocity near the primary tuyere is high because the volume change of solid phase is occurred as a result of the consumption of coke by the carbon monoxide combustion and the melting of scrap (the melting point was assumed to be $1400^{\circ} \mathrm{C}$ ). On the other hand, the velocity at the central zone of the furnace near the primary tuyere level is low in comparison with that in the peripheral zone. The heat exchange between gas and solid is performed promptly at the upper part of the furnace and the solid heating is promoted by the post combustion of $\mathrm{CO}$ gas caused by the air injection from the secondary tuyere as shown in $\mathrm{CO}_{2}$ profile of Fig. 11. The flow of liquid formed at the melting point has the distribution which is proportional to the solid velocity. The temperature of the dripping

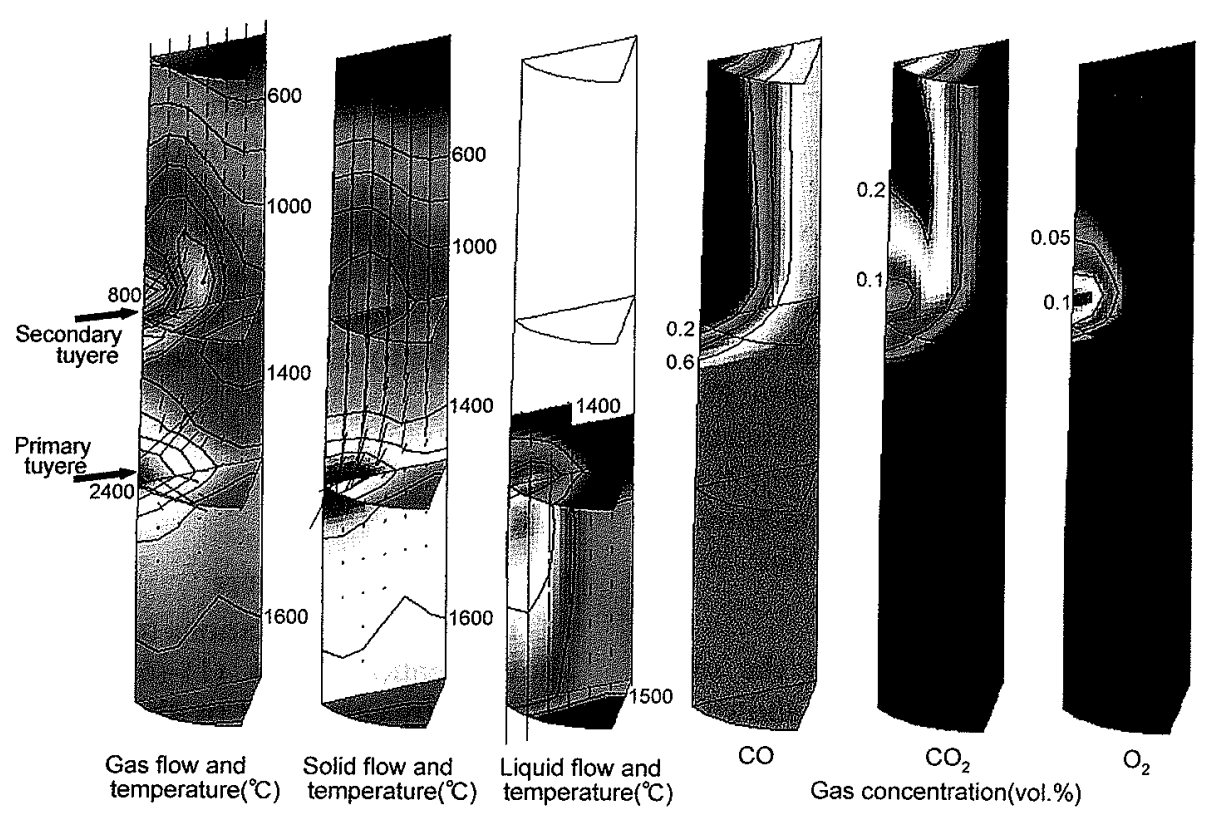

Fig. 11. Internal behavior of 1 ton furnace calculated by the present model. 


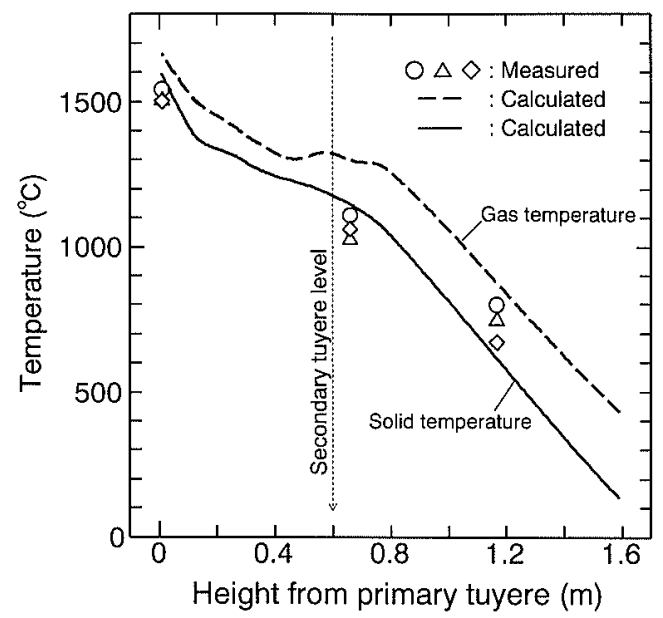

Fig. 12. Comparison of measured longitudinal temperature distribution with calculated one in the 1 ton furnace.

Table 6. Operational results of I ton furnace.

\begin{tabular}{|l|c|c|c|}
\hline Iterns & unit & Actual & Calculated \\
\hline Off gas temp. & ${ }^{\circ} \mathrm{C}$ & 340 & 407 \\
\hline Post combustion & $\%$ & 15.8 & 14.1 \\
\hline $\mathrm{O}_{2}$ rate & $\mathrm{Nm}^{3} / \mathrm{tHM}$ & 148 & 157 \\
\hline Fuel rate & $\mathrm{kg} / \mathrm{tHM}$ & 247 & 246 \\
\hline Production rate & $\mathrm{tHM} / \mathrm{hr}$ & 1.68 & 1.60 \\
\hline Hot metal temp. & ${ }^{\circ} \mathrm{C}$ & 1454 & 1464 \\
\hline$[\mathrm{C}]$ in $\mathrm{HM}$ & $\mathrm{wt}-\%$ & 4.38 & 4.23 \\
\hline
\end{tabular}

liquid near the furnace wall is higher than that in the other zone because of the dripping through the high temperature zone in front of the primary tuyere. The calculated longitudinal distribution of temperature in the furnace was good agreement with the observed one as shown in Fig. 12. Table 6 shows comparison of the overall actual operational results with the calculated ones. The validity of the model was confirmed from these results for the steady state simulation.

\subsection{Results on the 10 Ton BOF Type Test Converter}

In order to verify the validity of the model in respect of scaling up the large scale furnace from the small scale furnace, the simulation was performed on the actual operational data of the 10 ton BOF type test converter. The calculation was carried out with a special emphasis on the evaluation of dynamic response ability of the model. Process parameters was used the same ones which was used for the 1 ton furnace calculation. The operational condition for the simulation is shown in Table 7. The productivity $\left(\mathrm{t} / \mathrm{d} \cdot \mathrm{m}^{3}\right)$ of the 10 ton furnace is about 2.5 times as much as that of 1 ton furnace as shown in Table 7. The grids for the simulation are shown in Fig. 13. The number and position of tuyeres were designed based on the results of the 1 ton furnace simulation. The number of tuyeres were increased to repress deflection of gas and solid flow in the circumferential and radial direction with the scale up. Furthermore, the primary and secondary tuyeres were installed at staggered position in the circumferential direction as shown in Fig. 13 to avoid formation of remarkable high temperature zone inside the furnace. The computational region was treated a quarter of the furnace considering its symmetry. The calculation procedure was divided into two steps. At the first step,
Table 7. Operational conditions of 10 ton furnace.

\begin{tabular}{|c|c|c|}
\hline Items & Unit & Conditions \\
\hline Burden & \multirow[b]{2}{*}{$\begin{array}{l}\mathrm{mm} \\
\mathrm{mm} \\
- \\
\mathrm{m}\end{array}$} & \multirow[b]{2}{*}{$\begin{array}{c}217 \square \times 80 \mathrm{t} \\
40 \sim 80 \\
\text { separated } \\
1.9\end{array}$} \\
\hline $\begin{array}{l}\text { Scrap size } \\
\text { Coke size } \\
\text { Charging pattern } \\
\text { Stock level }\end{array}$ & & \\
\hline Blowing & \multirow[b]{2}{*}{$\begin{array}{l}\text { pieces } \\
\mathrm{Nm}^{3} / \mathrm{hr} \\
\mathrm{Nm}^{3} / \mathrm{hr} \\
- \\
\mathrm{Nm}^{3} / \mathrm{hr} \\
\mathrm{Nm}^{3} / \mathrm{hr} \\
{ }^{\circ} \mathrm{C} \\
\end{array}$} & \multirow[b]{2}{*}{$\begin{array}{l}4 p \\
779 \\
217 \\
0.65 \\
37.5 \\
2261 \\
2799\end{array}$} \\
\hline $\begin{array}{l}\text { Primary tuyeres } \\
\mathrm{O}_{2} \text { supply } \\
\mathrm{N}_{2} \text { supply } \\
\text { Coal/O } \\
\text { LPG supply } \\
\text { Bosh gas volume } \\
\text { Flame temperature }\end{array}$ & & \\
\hline $\begin{array}{l}\text { Secondary tuyeres } \\
\mathrm{O}_{2} \text { supply } \\
\mathrm{N}_{2} \text { supply } \\
\text { LPG supply }\end{array}$ & $\begin{array}{l}\text { pieces } \\
\mathrm{Nm}^{3} / \mathrm{hr} \\
\mathrm{Nm}^{3} / \mathrm{hr} \\
\mathrm{Nm}^{3} / \mathrm{hr}\end{array}$ & $\begin{array}{l}12 \mathrm{p} \\
513 \\
319 \\
12.8 \\
\end{array}$ \\
\hline $\begin{array}{l}\text { Bottom tuyeres } \\
\mathrm{O}_{2} \text { supply } \\
\mathrm{N}_{2} \text { supply } \\
\text { LPG supply }\end{array}$ & $\begin{array}{l}\text { pieces } \\
\mathrm{Nm}^{3} / \mathrm{hr} \\
\mathrm{Nm}^{3} / \mathrm{hr} \\
\mathrm{Nm}^{3} / \mathrm{hr}\end{array}$ & $\begin{array}{l}2 p \\
197 \\
100 \\
4.6 \\
\end{array}$ \\
\hline Productivity & \multirow[b]{2}{*}{$\begin{array}{l}\mathrm{tHM} / \mathrm{day} / \mathrm{m}^{3} \\
\mathrm{Nm}^{3} / \mathrm{hr} / \mathrm{m}^{3}\end{array}$} & \multirow[b]{2}{*}{$\begin{array}{l}46 \\
202 \\
\end{array}$} \\
\hline $\begin{array}{l}\text { Production rate } \\
\mathrm{O}_{2} \text { supply }\end{array}$ & & \\
\hline
\end{tabular}

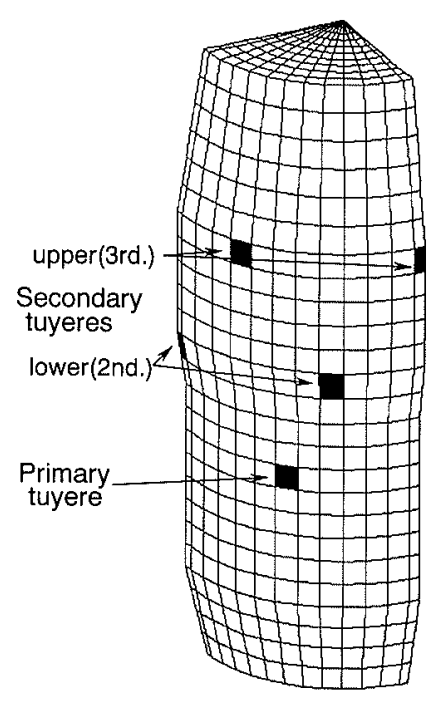

Fig. 13. Grids of 10 ton furnace.

the calculation was carried out to solve the initial condition of the internal states in the furnace that means the heating process of packed bed coke which was charged onto the bottom in the converter to form a packed bed of coke extending to just below the lower secondary tuyeres during the coke packing operation. In the second step, on the basis of this initial condition the calculation for the scrap melting operation was dynamically performed by the time difference $\Delta t(=10 \mathrm{~s})$ according to the transition of the blowing conditions as shown in Fig. 14. The transition of the operational results calculated by the model was well agreed with the actual operational results as shown in the figure. From this result the validity of the model was confirmed for the unsteady state simulation. Figure $\mathbf{1 5}$ shows the internal behavior after 2 hours from the start of the scrap melting operation calculated by the model. The internal states such as gas temperature and $\mathrm{CO}$ profile show three dimensional distribution and form non-uniform area. This behavior that flowery high temperature area was formed in the circumferential direction was also observed by a fiber scope equipped above the furnace. These 


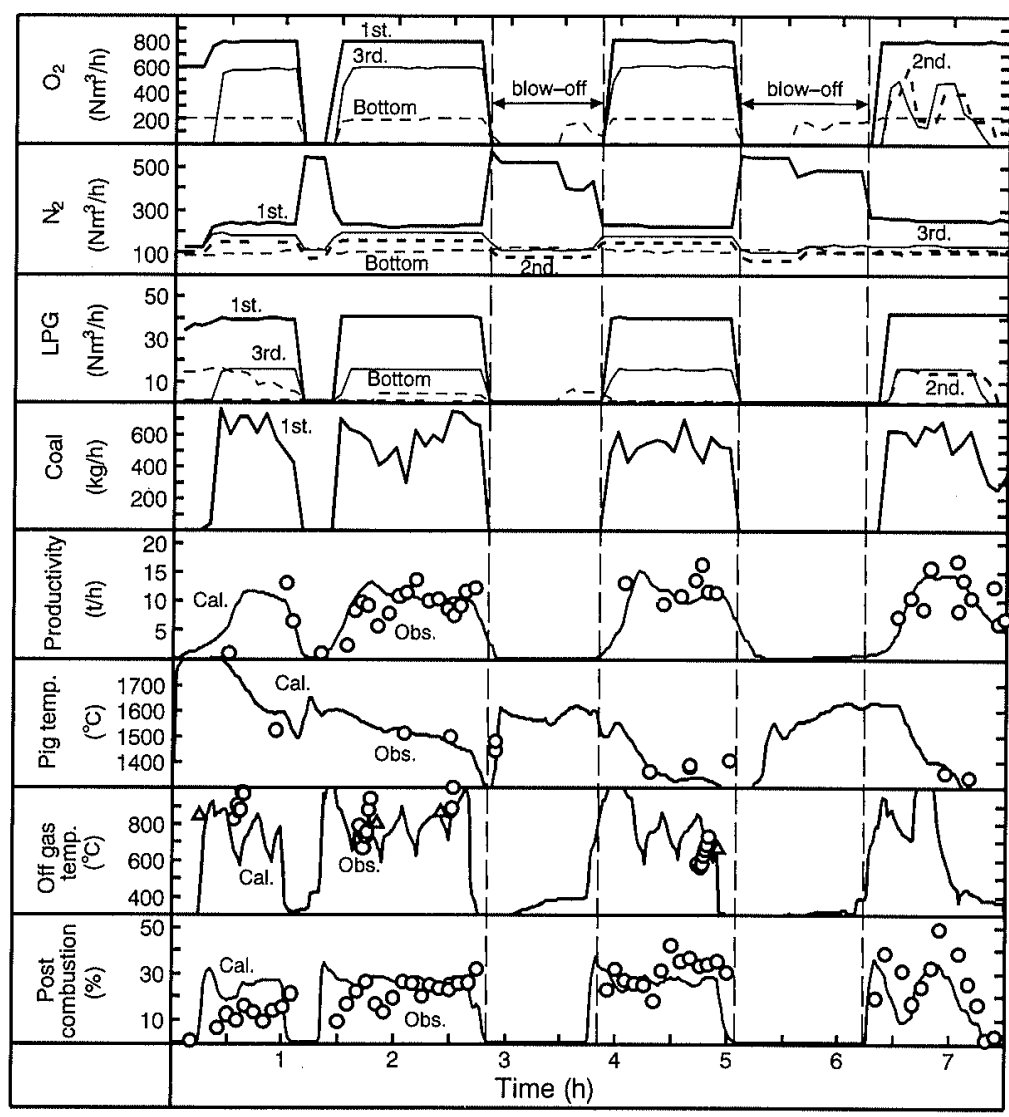

Fig. 14. Transition of the operational results calculated by the model for the actual operation of 10 ton furnace.

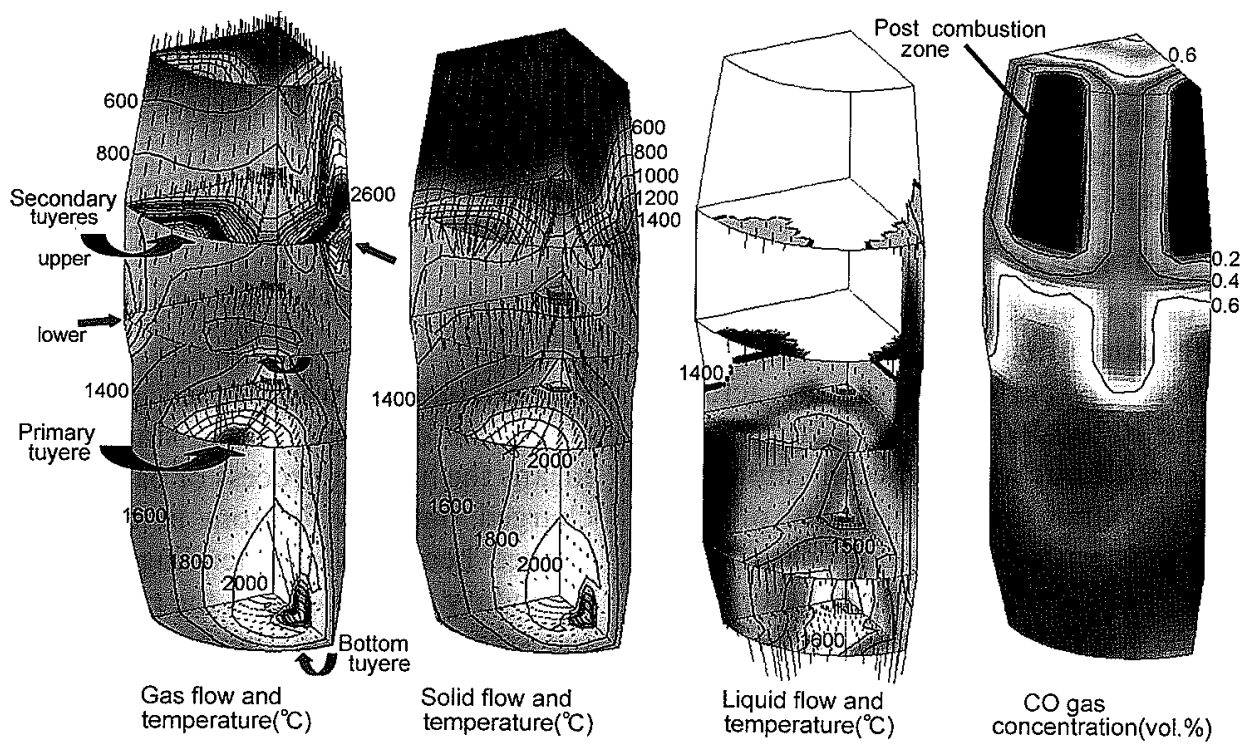

Fig. 15. Internal behavior of 10 ton furnace calculated by the present model.

indicate that there is a possibility for the number and the arrangement of tuyeres to have a great influence on the operational results. However, as remarkable high temperature zone does not exist and scrap is melt stably above the primary tuyeres as shown in this figure, it is found that the present setting of tuyeres is applicable. The discussion about three dimensional behavior is mentioned above and further study is necessary whether the more suitable setting for the arrangement of the secondary tuyeres is or not in order to achieve the more high heat efficiency with the best use of the sensitive heat
Table 8. Operational results of 10 ton furnace.

\begin{tabular}{|l|l|c|c|}
\hline Items & Unit & Actual & Calculated \\
\hline Off gas temp. & ${ }^{\circ} \mathrm{C}$ & 779 & 807 \\
\hline Off gas volume & $\mathrm{Nm}^{3} / \mathrm{hr}$ & 2744 & 2721 \\
\hline Post combustion & $\%$ & 23 & 23 \\
\hline Production & ton & 33 & 32 \\
\hline Hot metal temp. & ${ }^{\mathrm{C}}$ & 1440 & 1449 \\
\hline$[\mathrm{C}]$ in HM & $\%$ & 4.5 & 4.5 \\
\hline $\mathrm{O}_{2}$ rate & $\mathrm{Nm}^{3} / \mathrm{tHM}$ & 167 & 172 \\
\hline Coke rate & $\mathrm{kg} / \mathrm{tHM}$ & 158 & 151 \\
\hline Coal rate & $\mathrm{kg} / \mathrm{tHM}$ & 54 & 58 \\
\hline LPG rate & $\mathrm{kg} / \mathrm{tHM}$ & 12 & 13 \\
\hline Fuel rate & $\mathrm{kg} / \mathrm{tHM}$ & 224 & 222 \\
\hline
\end{tabular}


Table 9. Calculation condition for 160 ton furnace.

\begin{tabular}{|c|c|c|}
\hline Items & 10 ton $\mathrm{BOF}$ & 160 ton BOF \\
\hline \multicolumn{3}{|l|}{ Furnace dimension } \\
\hline Diameter & 1.8 & 5.6 \\
\hline Height & 3.6 & 8.0 \\
\hline Inner volume & 7.4 & 197 \\
\hline \multicolumn{3}{|l|}{ Operational condition } \\
\hline Scrap diameter & \multicolumn{2}{|c|}{175} \\
\hline Coke diameter & \multicolumn{2}{|c|}{60} \\
\hline$\left(\mathrm{Nm}^{3} / \mathrm{hr} / \mathrm{m}^{3}\right)$ & \multicolumn{2}{|c|}{245} \\
\hline Coal $/ 1^{\text {st }} \cdot \mathrm{O}_{2}$ & \multicolumn{2}{|c|}{0.8} \\
\hline $2^{\text {nd }} \cdot \mathrm{O}_{2} / 1^{\mathrm{st}} \cdot \mathrm{O}_{2}$ & \multicolumn{2}{|c|}{0.8} \\
\hline Flame temp. & \multicolumn{2}{|c|}{2240} \\
\hline Heat loss coefficient (Mcal $/ \mathrm{m}^{2} / \mathrm{hr} /{ }^{\circ} \mathrm{C}$ & \multicolumn{2}{|c|}{8.0} \\
\hline
\end{tabular}

Table 10. Effect of the production scale on operational results.

\begin{tabular}{|l|c|c|}
\hline Items & 10 ton BOF & 160 ton BOF \\
\hline Heat loss (Mcal/tHM) & 13.7 & 3.4 \\
\hline Fuel rate (kg/tHM) & 185 & 173 \\
\hline Post combustion $(\%)$ & 26 & 24 \\
\hline Off gas temp. $\left({ }^{\circ} \mathrm{C}\right)$ & 437 & 354 \\
\hline Production rate $\left(\mathrm{tHM} /\right.$ day $\left./ \mathrm{m}^{3}\right)$ & 46 & 47 \\
\hline Hot metal temp. $\left({ }^{\circ} \mathrm{C}\right)$ & 1400 & 1400 \\
\hline
\end{tabular}

of the post combustion in case of using relatively low height reactor like the BOF type furnace as the PSM process. Table 8 shows the comparison of overall operational results observed by the operation with that calculated ones during five hours from the start of the melting. A good agreement was also obtained regarding the overall heat and mass balance as shown in this table. Therefore, the scale up ability of the model was confirmed from these computed results.

\section{Estimation of Operational Results on the Commercial Scale PSM Process}

The calculation was performed to estimate the operational results of a commercial scale PSM process under the following assumptions.

1) The commercial scale plant was assumed 160 ton heat size BOF type converter.

2) Typical operational data of the 10 ton furnace was used as base data for the estimation.

3) Steady state operation is performed.

4) Scrap and coke are charged into the furnace with separated charging.

5) Burden distribution of the top of the furnace is uniform distribution.

6) Blowing conditions are not changed during the operation.

7) Heat loss coefficients $\left(\mathrm{kcal} / \mathrm{m}^{2} \cdot \mathrm{h} \cdot{ }^{\circ} \mathrm{C}\right)$ through the furnace wall and the bottom is constant regardless with the furnace scale.

Table 9 shows the dimension and calculation condition for the 160 ton BOF. The calculated results was shown in Table 10. The scrap melting ability of the commercial scale BOF was still maintained stable under the appropriate operational conditions as the same way as the 1 ton and 10 ton experimental furnaces even if the furnace was scaled up to the 160 ton BOF. It was estimated that the fuel rate went down by the decrease of heat loss rate that was reduced by the effect of the lower ratio of surface area/internal volume than its ratio of 10 ton furnace according to the scale up. From this result the scrap melting tests using the 10 ton BOF type furnace was confirmed to be an useful method to design the PSM commercial plant.

\section{Conclusions}

The following results were obtained through the scrap melting tests using the two furnaces (modified experimental blast furnace of 1 ton pig per tap scale and modified experimental BOF of 10 ton pig per tap scale) by the PSM method and the numerical analysis by the developed 3-dimensional mathematical simulation model.

1) $100 \%$ steel scrap can be melted using blast furnace coke and pulverized coal.

2) The hot metal whose quality is equal to that of blast furnace can be produced with high carburization $(\geqq 4$ mass $\% \mathrm{C})$ and high desulfurization $(\leqq 0.03$ $\operatorname{mass} \% \mathrm{~S})$.

3) High heat efficiency $(\geqq 80 \%)$ and high productivity $\left(50 \mathrm{t} / \mathrm{d} \cdot \mathrm{m}^{3}\right)$ were achievable.

4) High iron yield ( $\geqq 99$ mass $\% \mathrm{Fe}$ ) and low refractory erosion ( $\leqq 0.5 \mathrm{~mm} /$ charge) can be achieved by the packed scrap and coke.

5) The analysis of three dimensional and dynamic behavior of the process became possible and the experimental results using the two furnaces were well justified by the model.

6) A basic design of commercial scale plant was also performed by the use of the model. As a result, it was confirmed that the PSM method using commercial scale BOF was useful as a scrap melting process.

\section{Nomenclature}

$X:$ coordinate

$t:$ time

$D_{j}$ : effective diffusion coefficient of gas

$k_{j}$ : thermal conductivity of phase $j$

$C_{\mathrm{p} j}$ : mean heat capacity of phase $j$

$u_{j m}$ : heat transfer coefficient between phase $j$ and phase $m$

Rate $_{n}$ : rate of reaction $n$

$\Delta H_{n}:$ heat of reaction $n$

$M_{i}$ : molecular weight of species $i$

$a_{j i n}$ : stoichiometric constant of species $i$ of phase $j$ at reaction $n$

$a_{j m}: \quad$ contact area between phase $j$ and phase $m$

$d_{\mathrm{p}}:$ particle diameter

$T_{j}$ : temperature of phase $j$

$P$ : gas pressure

$U:$ velocity vector

$B$ : kinematic model's parameter

$\varepsilon_{j}:$ volume fraction of phase $j$

$\rho_{j}$ : density of phase $j$

$\xi_{j i}$ : mass fraction of species $i$ in phase $j$

$\eta_{j n}$ : distribution ratio to phase $j$ of the heat of reaction $n$

$\mu:$ viscosity of gas

$\phi$ : shape factor

Subscripts

1: liquid, s: solid, g: gas and $i, j, k$ : coordinates vector 


\section{REFERENCES}

1) T. Yamamoto: Symp. Recent Trends of New iron Production Process, ISIJ, Tokyo, (1996), 11.

2) K. Musaka: 114, 115 th Nishiyama Memorial Seminar ISIJ, Tokyo, (1986), 173.

3) M. Dietlin, J. J. Klein, M. Helleisen and F. Leclercq: Rev. Metall, Cah. Inf. Tech., 81 (1984), 734.

4) S. Okamura, H. Nakajima, K. Marukawa, M. Anezaki, Y. Tozaki, A. Mori, K. Katou, K. Ichihara: Tetsu-to-Hagané, 71 (1985), 1787.

5) T. Yamamoto, Y. Ujisawa, H. Ishida, T. Mori, H. Yamaoka and K. Marukawa: Metallurgical Process for Early Twenty Century, 2. TMS, (1994), 843.

6) H. Yamaoka and Y. Kamei: Tetst-to-Hagané, 79 (1993), 139.

7) S. Ogura: 114, 115th Nishiyama Memorial Seminar ISIJ, Tokyo, (1986), 8.

8) H. Ishida, K. Marukawa, S. Anezaki, T. Hirata and S. Shiode: Process Technology Conf. Proc. 7, ISS-AIME, (1988), 233.

9) J-P. Birat, Rémy Nicdle, M. Dietlin, M. Helleisen, J. J. Klein and M. Schneider: CAMP-ISIJ, 6 (1993), 1024.

10) Y. Ujisawa, H. Ishida, K. Takatani, T. Yamamoto and $H$. Yamaoka: CAMP-ISIJ, 7 (1994), 30.

11) Y. Ujisawa, H. Ishida, K. Takatani, T. Yamamoto and H. Yamaoka: CAMP-ISIJ, 7 (1994), 1140

12) J. Yagi and I. Muchi: Trans. Iron Steel Inst. Jpn., 10 (1970), 392.

13) R. Wartman: Stahl Eisen, 95 (1975), 442.

14) M. Hatano and K. Kurita: Trans. Iron Steel Inst. Jpn., 22 (1982), 448.

15) M. Hatano, K. Kurita, H. Yamaoka and T. Yokoi: Trans. Iron
Steel Inst. Jpn., 25 (1985), 933.

16) T. Sugiyama and M. Sugata: Seitetsu-Kenkyu, 325 (1987), 34

17) S. Ergun: Chem. Eng. Prog., 48 (1952), 89

18) R. M. Nedderman and U. Tuzun: Powder Technol., 22 (1979), 243.

19) Kagaku Kohgaku Binran Kaitei Shan, Maruzen, Tokyo, (1998) 988.

20) K. Takatani, Y. Ujisawa and H. Yamaoka: CAMP-ISIJ, 2 (1989), 1030.

21) H. Yamaoka and Y. Kamei: Tetsu-to-Hagané, 74 (1988), 2254.

22) I. Ohnaka and T. Fukusako: Tians Iron Steel Inst. Jpn., 17 (1977), 410 .

23) Y. Iwanaga and K. Takatani: J. Fuel Soc. Jpn., 68 (1989), No. 4.

24) K. Takatani and Y. Iwanaga: Tetsu-to-Hagané, 75 (1989), 594.

25) W. E. Ranz: Chem. Eng. Prog., 48 (1952), 247.

26) W. H. Giedt: Principles of Engineering Heat Transfer, transl. by S. Yokobori and O. Kuga, Maruzen, Tokyo, (1957), 146 and 281.

27) Kagaku Kohgaku Binran Kaitei 5han, Maruzen, Tokyo, (1998), 355 .

28) Kagaku Kohgaku Binran Kaitei 4han, Maruzen, Tokyo, (1978), 58.

29) K. Onda, H. Takeuchi and K. Koyama: Kagaku-Kougaku, 31 (1967), 127.

30) J. Umada, H. Shinohara and H. Tsubakihara: Kagaku-Kougaku, 27 (1963), 978.

31) K. Takatani: Tetsu-to-Hagané, 74 (1988), 1546.

32) C. W. Hirt, B. D. Nichls and N. C. Romero: SOLA-A Numerical Solution Algorithm for Transient Fluid Flows, Los Alamos Sci. Lab, Los Alamos, (1975), LA-5852.

33) P. J. Roache: Computational Fluid Dynamics, Hermora Publishers, (1976) 